\title{
Incorporation of medium chain fatty acids into fish oil triglycerides by chemical and enzymatic interesterification
}

\author{
By Maria M. C. Feltes, ${ }^{a}$ L. de Oliveira Pitol, ${ }^{a}$ J. F. Gomes Correia, ${ }^{a}$ R. Grimaldi, ${ }^{b}$ \\ J. Mara Block ${ }^{\mathrm{c}}$ and Jorge L. Ninow, ${ }^{\mathrm{a}}{ }^{*}$
}

\author{
${ }^{a}$ Centro Tecnológico, Departamento de Engenharia Química e Engenharia \\ de Alimentos, Universidade Federal de Santa Catarina (UFSC), \\ Caixa Postal 476, CEP 88040-900, Florianópolis, SC, Brazil \\ ${ }^{\mathrm{b}}$ Faculdade de Engenharia de Alimentos, Laboratório de Óleos e Gorduras, \\ Universidade Estadual de Campinas (UNICAMP), Campinas, SP, Brazil. \\ ${ }^{c}$ Centro de Ciências Agrárias, Departamento de Ciência de Alimentos (UFSC), \\ Florianópolis, SC, Brazil. \\ $\left({ }^{\star}\right.$ Corresponding author: jorge @enq.ufsc.br)
}

\section{RESUMEN}

Incorporación de ácidos grasos de cadena media a triglicéridos de aceite de pescado por interesterificación química y enzimática.

Triglicéridos estructurados (SL) conteniendo ácidos grasos de cadena media (MCFA) y ácidos grasos poliinsaturados (PUFA) en la misma molécula de glicerol tienen ventajas nutricionales y terapéuticas. Se establece la incorporación de MCFA a los triglicéridos (TAGs) de aceite de pescado, conservando un contenido considerable de ácidos docosahexaenóico (DHA) y eicosapentaenóico (EPA). El efecto de diferentes acil donadores (éster metílico de ácido cáprico/ $/ \mathrm{MeC}_{10}$ o triglicéridos de cadena media/TCM) y de catalizador (químico o enzimático) sobre la composición del producto de las reacciones fue estudiado. La composición de ácidos grasos de los TAGs del aceite de pescado fue modificada después de las reacciones para contener MCFA y dependió del catalizador y de los substratos. Los termogramas obtenidos por Calorimetría Diferencial de Barrido (DSC) indicaron que la interesterificación provocó alteraciones considerables de los perfiles de fusión de las muestras. Fueron producidos STs de interés en nutrición clínica conteniendo EPA y DHA, además de MCFA.

PALABRAS-CLAVE: Aceite de pescado - Ácidos grasos de cadena media - Interesterificación - Triglicéridos estructurados.

\section{SUMMARY}

Incorporation of medium chain fatty acids into fish oil triglycerides by chemical and enzymatic interesterification.

Structured triglycerides (STs) containing both mediumchain fatty acids (MCFA) and polyunsaturated fatty acids (PUFA) in the same molecule offer nutritional and therapeutic benefits. The aim of this work was to establish the incorporation of MCFA into fish oil triglycerides (TAGs), while maintaining substantial levels of docosahexaenoic and eicosapentaenoic acids. The effects of different acyl donors (capric acid methyl ester/ $\mathrm{MeC}_{10}$ or medium chain triglyceride/TCM) and of the catalyst (chemical or enzymatic) on the fatty acid composition of the reaction product were studied. The fatty acid composition of the fish oil TAG was modified after interesterification to contain MCFA, and it depended on the catalyst and on the substrates. Thermograms obtained by Differential Scanning Calorimetry (DSC) showed that interesterification promoted noteworthy changes in the melting profile of the samples. STs of clinical nutrition interest containing both EPA and DHA obtained from fish oil along with MCFA were successfully produced.

KEY-WORDS: Fish oil - Interesterification - Mediumchain fatty acid - Structured triglycerides.

\section{INTRODUCTION}

Medium-chain triglycerides (MCTs) containing medium-chain saturated fatty acids (MCFA, C6:0 to C12:0), show higher mobility and solubility than long-chain fatty acids (LCFA), and they are rapidly and almost completely oxidized (Bell and Bradley, 1997; Dunford, 2004; Jones et al., 2006; St-Onge and Borsarge, 2008). Therefore, MCTs are largely applied as lipid substrates in enteral and parenteral nutrition, providing energy for patients suffering from a number of disorders (Goldberg, 1994; Galante and Tenore, 2006; Nielsen et al., 2005; Mu and Porsgaard, 2005). MCT fats, however, have reduced palatability and lower digestibility than other fatty acids (Nielsen et al., 2005). Although MCFAs, mainly caprylic and capric acids, seem to be neutral with respect to their low-density lipoproteinscholesterol (LDL-C) raising properties (Nicolosi, 1997), there are some concerns regarding the possible effects of MCFA consumption on plasma lipid concentrations (Cater et al., 1997; Kubow, 1996; Osborn and Akoh, 2002; St-Onge, 2005). Therefore, caprylic and capric acids are more useful in combination with long-chain polyunsaturated fatty acids (PUFAs) in formulas to provide essential fatty acids via the PUFAs (Mu and Hoy, 2000; Osborn and Akoh, 2002; Hartvigsen et al., 2003).

Commercial lipid emulsions containing a physical mixture of long-chain triglycerides (LCT) together with MCT have been used for years in 
clinical nutrition (Osborn and Akoh, 2002; Carpentier, 2008; Simoens et al., 2008). The inclusion of e docosahexaenoic acid (DHA, C22:6n3 ) and eicosapentaenoic acid (EPA, C20:5n-3) from marine origin in lipid emulsions could supply eicosanoids derived from EPA (Bell and Bradley, 1997; Stein, 1999), which offer physiological benefits (Pigott and Tucker, 1990; Hasselmann and Kummerlen, 1998; Kris-Etherton et al., 2002; Hartvigsen et al., 2003; Soccol and Oetterer, 2003), especially in acutely ill patients and in patients receiving long-term parenteral nutrition (Bourque et al., 2003; Qi et al., 2006).

In recent years, extensive research has been focused on interesterification reactions for the synthesis of specific triglycerides known as structured triglycerides (STs), with optimal properties as a result of modifications either to the fatty acid (FA) composition or a positional redistribution of the acyl groups bonded to the glycerol backbone of the original TAGs (Akoh, 1995; Willis et al., 1998; Xu, 2004).

Based on these considerations, randomized or specific STs containing a mixture of MCFA and LCFA in the same molecule have been designed for medical purposes (Stein, 1999; Mu and Porsgaard, 2005; Carpentier, 2008). Lipid emulsions containing specific STs demonstrate improved hydrolysis and absorption in comparison with a randomized ST or a physical mixture of MCT and LCT (Bistrian, 1997; Stein, 1999; Straarup and Hoy, 2000; Xu, 2004). During digestion, a fat containing MCFAs located in the $s n-1,3$ positions of the glycerol backbone is rapidly hydrolyzed mainly via the portal vein; while the PUFA located in the position 2 of the same molecule is delivered as 2-monoglyceride, which will be absorbed efficiently via the lymphatic route and therefore will be incorporated into different tissues (Jandacek et al., 1987; Mu and Hoy, 2000; Mu and Hoy, 2001; Versleijen et al., 2005; Nielsen et al., 2005; Carpentier, 2008). A diet rich in such a specific ST may reduce the incorporation and storage of dietary fats and oils into adipose tissue, increase the total carcass protein amount and significantly reduce serum cholesterol levels, with no genotoxic potential (Matulka et al., 2006).

In interesterification reactions, the exchange of fatty acids within (rearrangement) or among molecules may occur in a random or in a specific way, depending on the catalyst (Macrae 1983; Willis et al., 1998). Chemical catalysis has been extensively applied to ST synthesis especially because of the low cost of the catalyst and because of its efficiency even at low concentrations (Marangoni and Rousseau, 1995; Klinkesorn et al., 2004). The chemical reaction, however, cannot be performed in an acid environment (Christie, 1982). A good alternative for overcoming the problem of the presence of the free fatty acid in the environment is its conversion into its alkyl ester (Klinkesorn et al., 2004). Moreover, chemical interesterification produces a complete randomization of acyl groups in TAGs (Akoh, 1995; Osborn and Akoh, 2002).
The transformation of oils mediated by lipases has been extensively studied (Macrae, 1983; Gunstone, 1999; Osborn and Akoh, 2002). Biocatalysis takes advantage of the specificity of some lipases thus allowing the production of useful molecules which cannot be obtained either chemically or naturally (Akoh, 1995; Marangoni and Rousseau, 1995; Shimada, 2006). The sn-1,3specific lipases have been used in the range of 5 to $10 \%$ by weight of reactants to promote the incorporation, for example, of capric acid into the end positions of a TAG molecule whose central position is preferentially occupied by fatty acids of nutritional interest (Gunstone et al., 1994).

The aim of the present paper was to establish the interesterification reaction that could lead to the design of STs of clinical nutrition interest, containing MCFA along with a high n-3 EPA and DHA content. This report compares the results obtained from the fatty acid composition of the interesterified oils when using chemical (with sodium methoxide/ $\mathrm{NaOCH}_{3}$ as catalyst) and enzymatic interesterification (with a commercial immobilized sn-1,3-specific lipase). In both cases, a commercial fish oil was used as substrate and two substances were evaluated as acyl donors (capric acid methyl ester/MeC $\mathrm{Me}_{10}$ and medium chain triglycerides/TCM).

\section{MATERIALS AND METHODS}

\subsection{Materials}

Capric acid was obtained from Sigma Chemical Co. ROPUFA n-3 "30" Food Oil was supplied by DSM Nutritional Product Ltd. Trigliceril $\mathrm{CM} \otimes$ was obtained from Support Produtos Alimenticios Ltda, Brazil. Lipozyme ${ }^{\circledR}$ RMIM was gift from Novozymes. This lipase is sn-1, 3-specific.

\subsection{Interesterification reactions}

Capric acid (C10:0) was esterified according to Klinkesorn et al. (2004). The $\mathrm{MeC}_{10}$ was stored at $-20{ }^{\circ} \mathrm{C}$ in a nitrogen atmosphere until use. For the reactions, the substrates were mixed as follows: ROPUFA ${ }^{\circledR}: \mathrm{MeC}_{10}(1: 2, \mathrm{~mol} / \mathrm{mol})$ and ROPUFA ${ }^{\circledast}$ :Trigliceril $\mathrm{CM}^{\circledR}(1: 1, w / w)$. Before the reaction, the samples were dried using a vacuum rotary evaporator at $90-95{ }^{\circ} \mathrm{C}$ for $1 \mathrm{~h}$. Reactions were performed as described below.

For the chemical reaction, sodium methoxide $\left.(\mathrm{NaOCH})_{3}\right)$ was prepared by heating the mixture $\mathrm{NaOH}: \mathrm{MeOH}(1: 25, \mathrm{w} / \mathrm{v})$ to $60^{\circ} \mathrm{C}$ while stirring until the complete dissolution of the reactants. The solvent was removed at $60{ }^{\circ} \mathrm{C}$ using a vacuum rotary evaporator. The catalyst was stored in a dark flask in a desiccator until use. The chemical interesterification was performed according to Díaz Gamboa and Gioielli (2003a). The reaction was carried out with magnetic stirring in a water bath. After the mixture of reactants had reached the 
reaction temperature $\left(60{ }^{\circ} \mathrm{C}\right), \mathrm{NaOCH}_{3}$ in fine powder was added at a mass ratio of $0.4 \%$ of reactants. After $1 \mathrm{~h}$ under a vacuum of $56 \mathrm{mmHg}$ the reaction was stopped with the addition of 0.5 $\mathrm{mL}$ of an aqueous solution of $4 \%(\mathrm{~m} / \mathrm{v})$ citric acid (Klinkesorn et al., 2004).

For the enzymatic interesterification, the temperature was kept at $60^{\circ} \mathrm{C}$ (Moura et al., 2006). The lipase Lipozyme RM IM ${ }^{\circledR}$ was added at a mass ratio of $5 \%$ of reactants. The reaction took place for $6 \mathrm{~h}$ with magnetic stirring under a vacuum of 56 $\mathrm{mmHg}$ (Díaz Gamboa and Gioielli, 2003a) and it was stopped by the removal of the immobilized enzyme through centrifugation (3,000 rpm for 15 min) and filtration.

The interesterified oils were stored at $-20{ }^{\circ} \mathrm{C}$ in nitrogen until analysis.

\subsection{Analytical Methodology}

\section{Determination of the quality of the samples}

The acid value (Method $\mathrm{Ca} 5 \mathrm{a}-40$ ) and the peroxide value (Method Cd 8-53) of the ROPUFA n3 '30' Food Oil ${ }^{\circledR}$ (DSM Nutritional Products Ltd) were determined according to the Official Methodology of the American Oil Chemists' Society (AOCS, 1990). The iodine value (I.V.) of the original mixture of the oils and the interesterified oils was calculated according to the expanded formula from the American Oil Chemists' Society Official Method Cd 1c-85 (AOCS, 1997).

\section{Fatty acid composition}

After interesterification reactions, TAG fractions were isolated from interesterified oils by thin-layer chromatography (TLC) on $20 \mathrm{~cm}$ silica gel 60G plates containing a fluorescent reactant (MachereyNagel, Germany) using the elution system hexane/ethyl ether/formic acid (80:20:2, v/v/v) (Christie, 1982).

The fatty acid composition of the samples

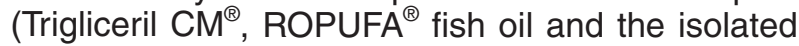
TAGs from the interesterified oils) was determined by GC after the conversion of fatty acids into their fatty acid methyl esters (Hartman and Lago, 1973). The gas chromatograph was a Shimadzu (Shimadzu Co., Japan) 17A model, equipped with a flame-ionization detector and an SP 2340 fusedsilica capillary column $(60 \mathrm{~m} \times 0.25 \mathrm{~mm}, 0.2 \mu \mathrm{m}$ of polyethyleneglycol, Supelco). The injector and detector temperatures were 240 and $260{ }^{\circ} \mathrm{C}$, respectively. The column temperature was held at $120{ }^{\circ} \mathrm{C}$ for $5 \mathrm{~min}$, then programmed to $240{ }^{\circ} \mathrm{C}$ at $4{ }^{\circ} \mathrm{C} \cdot \mathrm{min}^{-1}$ and held for $5 \mathrm{~min}$. The carrier gas used was helium set at a flow rate of $0,67 \mathrm{~mL} \cdot \mathrm{min}^{-1}$ (the linear speed was $17 \mathrm{~cm} . \mathrm{s}^{-1}$ ). The qualitative fatty acid composition was determined by comparing the retention times of the sample peaks with respective fatty acid methyl ester standards (Supelco 37 components FAMEs Mix, ref. 47885-U). The quantitative fatty acid determination was accomplished by area normalization and expressed as mass percent.

\section{Differential scanning calorimetry analysis}

The differential scanning calorimetry (DSC) analysis was performed according to the Method Cj 1-94 (AOCS, 1997) using a power compensation differential calorimeter (Model Delta Series DSC 7, PERKIN ELMER). The DSC melting and crystallization curves were obtained for the samples before and after interesterification. Analysis conditions: weight of samples: $\sim 10 \mathrm{mg}$; melting curves: $10 \min \left(80{ }^{\circ} \mathrm{C}\right) ; 80{ }^{\circ} \mathrm{C}$ to $-40{ }^{\circ} \mathrm{C}$ $\left(10^{\circ} \mathrm{C} \cdot \mathrm{min}^{-1}\right)$; $30 \mathrm{~min}$ at $-40{ }^{\circ} \mathrm{C} ;-40{ }^{\circ} \mathrm{C}$ to $80{ }^{\circ} \mathrm{C}$ $\left(5^{\circ} \mathrm{C} \cdot \mathrm{min}^{-1}\right)$. The following parameters were obtained

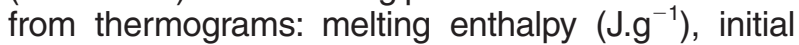
and final melting temperatures $\left({ }^{\circ} \mathrm{C}\right)$, onset melting temperature $\left({ }^{\circ} \mathrm{C}\right)$, and maximum peaks $\left({ }^{\circ} \mathrm{C}\right)$.

\section{RESULTS AND DISCUSSION}

The acid and the peroxide values of the ROPUFA $^{\circledR}$ fish oil were $0.44 \%$ of oleic acid and 1.46 meq $\mathrm{O}_{2} \cdot \mathrm{kg}^{-1}$, respectively. These results agree with supplier specifications and match international regulations whose criteria of quality for refined oil include a peroxide value lower than 10 meq $\mathrm{O}_{2} \cdot \mathrm{kg}^{-1}$ (FAO-WHO, 1981, revision 1999) or $5 \mathrm{meq} \mathrm{O} \cdot \mathrm{kg}^{-1}$ in the case of oil extracted from herring (FDA, 1995, revision 2003).

The fatty acid composition of the samples as determined by GC is shown in Table 1. The total n3 fatty acid content in the original ROPUFA ${ }^{\circledR}$ fish oil was $31.92 \%$, with a predominance of EPA and $\mathrm{DHA}$, and no MCFA was identified in this sample. Such a composition is a characteristic feature of marine oils (Pigott and Tucker, 1990; Aro et al., 2000). Capric and caprylic acids were responsible for more than $98 \%$ of the Trigliceril $\mathrm{CM}^{\circledR}$ fatty acid composition.

The choice of the reaction conditions during synthesis of the STs was based on a previous study concerning the chemical and the enzymatic synthesis of STs containing MCFAs from palm kernel fat and n-3 PUFAs from fish oil (Díaz Gamboa and Gioielli, 2003a). The conditions applied by these authors for the enzymatic reaction are in agreement with other results found in the literature for similar substrates (Jennings and Akoh, 1999; Jennings and Akoh, 2001). In the latter work, these authors have observed that a high incorporation of capric acid into fish oil was achieved at an enzyme load of $5 \%$ (by mass of substrates) for the solvent-free reaction using the lipase Lipozyme ${ }^{\circledR}$ RM IM. The enzymatic reaction temperature was established in accordance with another work involving the reaction between $n-3$ PUFA ethyl esters and MCT (Moura et al., 2006). In the present study, the substrates were mixed in a ratio that allowed the inclusion of the capric acid 
Table 1

Fatty acid composition (\%, w/w) of ROPUFA ${ }^{\circledR}$ food oil, trigliceril CM ${ }^{\circledR}$ (TCM) and their interesterified triglycerides

\begin{tabular}{|c|c|c|c|c|c|c|}
\hline \multirow[b]{2}{*}{ Fatty acid } & \multirow[b]{2}{*}{ ROPUFA $^{\circledR}$} & \multirow[b]{2}{*}{ Trigliceril $\mathbf{C M}^{\circledR}$} & \multicolumn{2}{|c|}{ Trigliceril CM $^{\circledast}+$ ROPUFA $^{\circledR}$} & \multicolumn{2}{|c|}{ MeC $_{10}+$ ROPUFA $^{\circledR}$} \\
\hline & & & After $\mathbf{C l}^{\mathrm{a}}$ & After $\mathrm{El}^{\mathrm{b}}$ & After $\mathbf{C l}$ & After El \\
\hline C6:0 & - & 1.23 & - & - & - & - \\
\hline C8:0 (Caprylic) & - & 63.13 & 14.04 & 18.68 & 0.10 & 0.70 \\
\hline C10:0 (Capric) & - & 34.99 & 10.35 & 11.22 & 4.44 & 9.04 \\
\hline C12:0 & - & 0.61 & - & - & - & - \\
\hline C14:0 & 6.49 & - & 5.56 & 4.75 & 6.22 & 6.05 \\
\hline C14:1 & 0.30 & - & - & - & - & - \\
\hline C15:0 & 1.05 & - & - & - & 0.68 & 0.66 \\
\hline C16:0 & 19.58 & - & 19.42 & 15.50 & 18.98 & 17.44 \\
\hline C16:1 & 5.97 & - & 4.39 & 3.59 & 6.75 & 6.52 \\
\hline C17:0 & 0.72 & - & - & - & 0.55 & 0.61 \\
\hline C17:1 & 0.54 & - & - & - & - & - \\
\hline C18:0 & 3.65 & - & 3.42 & 2.80 & 3.66 & 3.26 \\
\hline C18:1n9t & 2.36 & - & - & - & - & - \\
\hline C18:1n9c & 17.38 & - & 19.38 & 15.83 & 20.01 & 18.03 \\
\hline C18:2n6c & 2.99 & - & 2.51 & 2.15 & 3.39 & 0.12 \\
\hline $\mathrm{C} 20: 0$ & 0.62 & - & - & - & 1.91 & 0.40 \\
\hline C18:3n6 & 0.25 & - & - & - & - & - \\
\hline C18:4n3 & 1.94 & - & - & - & - & - \\
\hline C20:1 & 1.10 & - & - & - & 1.86 & 1.95 \\
\hline C18:3n3 & 1.26 & - & - & - & 1.78 & 2.11 \\
\hline C20:2 & 0.39 & - & - & - & 0.45 & 0.39 \\
\hline C22:0 & 0.27 & - & - & - & - & 0.18 \\
\hline C20:3n6 & - & - & - & - & 1.51 & 1.21 \\
\hline C20:3n3 & - & - & - & - & 0.78 & 0.71 \\
\hline C22:2 & 0.24 & - & - & - & - & - \\
\hline C20:4n6 & 0.97 & - & - & - & - & 0.74 \\
\hline C20:5n3 (EPA) & 11.17 & - & 7.51 & 12.33 & 11.06 & 11.85 \\
\hline $\mathrm{C} 22: 5 \mathrm{n} 3$ & 1.07 & - & - & - & 0.68 & 0.53 \\
\hline C22:6n3 (DHA) & 19.68 & - & 13.42 & 13.17 & 15.19 & 17.52 \\
\hline Total & 100.00 & 100.00 & 100.00 & 100.00 & 100.00 & 100.00 \\
\hline Saturated & 32.38 & 100.00 & 52.79 & 52.95 & 36.54 & 38.34 \\
\hline Monounsaturated & 27.65 & - & 23.77 & 19.42 & 28.62 & 26.50 \\
\hline Polyunsaturated & 39.96 & - & 23.44 & 27.65 & 34.84 & 35.18 \\
\hline Total & 100.00 & 100.00 & 100.00 & 100.00 & 100.00 & 100.00 \\
\hline $\mathrm{EPA}+\mathrm{DHA}$ & 30.85 & - & 20.93 & 25.50 & 26.25 & 29.37 \\
\hline EPA:DHA & 0.57 & - & 0.56 & 0.94 & 0.73 & 0.68 \\
\hline n3:n6 & 8.34 & - & 8.34 & 11.86 & 6.02 & 15.81 \\
\hline lodine value & 187 & - & 120 & 134 & 157 & 166 \\
\hline
\end{tabular}

${ }^{a}$ After $\mathrm{Cl}=$ After chemical interesterification.

${ }^{\mathrm{b}}$ After $\mathrm{El}=$ After enzymatic interesterification.

into two positions of the ROPUFA ${ }^{\circledR}$ triglycerides when the $\mathrm{MeC}_{10}$ was applied as substrate (1:2, mol:mol, ROPUFA $\left.{ }^{\circledR}: \mathrm{MeC}_{10}\right)$, as previously stated by Jennings and Akoh (1999) for the esterification of capric acid to fish oil TAG by means of an enzymatic reaction with the lipase Lipozyme ${ }^{\circledR} \mathrm{RM} I \mathrm{IM}$. In the case of the interesterification between the ROPUFA $^{\circledR}$ and the Trigliceril $\mathrm{CM}^{\circledR}$, the ratio $1: 1$ (w/w) was chosen because it is usually applied for the physical mixture of LCT and MCT applied in enteral and parenteral nutrition (Hasselmann and Kummerlen, 1998).

After both the chemical and the enzymatic reaction between the fish oil and the acyl donor (Trigliceril $\mathrm{CM}^{\circledR}$ or $\mathrm{MeC}_{10}$ ), MCFAs were detected in the TAGs of the interesterified oils. This composition confirms the exchange of acyl groups among substrates during interesterification (Reyes and Hill, 1994; Marangoni and Rousseau, 1995; Rousseau and Marangoni, 2002; Xu, 2004).

In this study, the reaction conditions favored the occurrence of chemical interesterification: the concentration of the catalyst $(0.4 \%$ by weight of reactants) was greater than concentrations commonly used $(0.1-0.2 \%$ by weight) (Marangoni and Rousseau, 1995), while the media was extremely apolar, and there was also no solvent.

Despite this, MCFA incorporation was greater for the enzymatic reaction than for the chemical reaction regardless of the substrate. Furthermore, the EPA and DHA content of the enzymatically interesterified oils remained close to that of the 
original values. These results agree with others which show that lipases discriminate strongly between MCFA and LCFA in favor of MCFA (Akoh, 1995; Kubow, 1996; Bell and Bradley, 1997; Osborn and Akoh, 2002).

The use of $\mathrm{MeC}_{10}$ as acyl donor led to a higher content of EPA and DHA after the reaction. The total EPA and DHA content in the interesterified Trigliceril $\mathrm{CM}^{\circledR}$ and ROPUFA ${ }^{\circledR}$ oils was $20.93 \%$ and $25.50 \%$ for the chemical and the enzymatic reactions, respectively. The total EPA and DHA content in the $\mathrm{MeC}_{10}$ and the ROPUFA ${ }^{\circledR}$ oil was $26.25 \%$ and $29.37 \%$ after chemical and enzymatic interesterification, respectively. The success of the use of methyl esters as substrates for interesterification reactions has been previously demonstrated in another study whose objective was the enrichment of tuna oil with EPA and DHA by chemical transesterification (Klinkesorn et al., 2004).

A previous study (Moura et al., 2006) also reported the efficiency of the incorporation of longchain esters (of the ethyl type), obtained from fish oil, into MCT, at a molar ratio of $1: 2.5$, respectively, by using a $s n-1,3-$ specific lipase $(5 \%$ by weight of reactants), without previous conditioning. After $30 \mathrm{~h}$ at $60^{\circ} \mathrm{C}$ with stirring and under vacuum, the highest incorporation of esters $(66.66 \%)$ into the end position of the TAGs was reached, thus obtaining a specific ST with nutritional interest.

In another study, the incorporation of C10:0 into fish oil TAGs (Pronova Biocare, Noruega), at a molar ratio of $2: 1$, respectively, was performed over $24 \mathrm{~h}$ at $55^{\circ} \mathrm{C}$ and 200 rpm by using an immobilized sn1,3-specific lipase (10\% by weight of reactants). The authors obtained a final product with an average of $43 \mathrm{~mol} \%$ of C10:0 in TAGs for the reaction in the presence of hexane, and $31.8 \mathrm{~mol} \%$ for the solventfree reaction. It was found that EPA and DHA were predominantly located in the central position of TAGs, thus confirming the ST synthesis, even with some acyl migration (Jennings and Akoh, 1999).

The same researchers outlined the same reaction conditions for the enzymatic modification of another fish oil (menhaden fish oil from National Marine Fisheries Service, USA). TAGs were produced with an average of $28.8 \mathrm{~mol} \%$ of $\mathrm{C} 10: 0$, predominantly located in the end positions (Jennings and Akoh, 2001).

Others have described the possibility of the synthesis of STs containing MCFAs, EPA and DHA by both chemical and enzymatic interesterification of binary mixtures between palm kernel oil (rich in lauric acid) and fish oil. The chemical reaction was performed over $1 \mathrm{~h}$ at $60^{\circ} \mathrm{C}$ with stirring and under reduced pressure, with sodium methoxide as catalyst $(0.4 \%$ by weight of reactants). A final product was obtained with plastic behavior and containing 5.0 to $23.4 \%$ of n-3 PUFAs (Díaz Gamboa and Gioielli, 2003a). The enzymatic interesterification was carried out over $6 \mathrm{~h}$ at $65^{\circ} \mathrm{C}$ in a nitrogen atmosphere by using a commercial sn1,3-specific lipase (5\% by weight of reactants) (Díaz Gamboa and Gioielli, 2003b).
Table 1 shows that both the original fish oil and the interesterified oils exhibited a value DHA greater than that of EPA and all samples containing fish oil were important sources of $n-3$ fatty acids. The I.V. of the original fish oil was $187 \mathrm{~g}$ iodine $/ 100 \mathrm{~g}$ oil. This high I.V. is associated with the unsaturated fatty acids present in the sample, which is consistent with other studies involving fish oils (Pacheco and BarreraArellano, 1994; Wanasundara and Shahidi, 1998). As expected (Nassu and Gonçalves, 1999), the I.V. of the samples decreased as MCFA was incorporated, especially when using the Trigliceril $\mathrm{CM}^{\circledR}$ as substrate, which has a high oxidative stability (Akoh et al., 1998).

Such results indicated that the obtained STs are more stable in storage than the original fish oil, which is important considering the sensitivity of PUFAs to peroxidative damage (Carpentier, 2008). Also, their content of MCFAs may supply significant energy intake and their content of PUFAs may prevent a deficiency of essential fatty acids, thereby helping modulate important metabolic reactions (Lands, 2002; Carpentier, 2008).

The lipid emulsion formulas have to provide not only the nutrient composition necessary for the patients, but also the physical characteristic requirements for their administration in enteral or parenteral nutrition. Once lipid emulsions containing MCTs have low melting points and viscosity, they are liquid products that can be administered in their pure form or as a main vehicle from pharmaceutical formulas (Bach and Babayan, 1982; Goldberg, 1994; Akoh et al., 1998).

In mixed-acid triglycerides, not only the fatty acid composition, but also the position to which the fatty acids are esterified would have influence on the melting point and the fluidity of the oil, and therefore on its digestibility (Bockisch, 1993; Christophe, 1998; Rousseau and Marangoni, 2002; Nielsen et al., 2005). The differences in the chain lengths and a residue in an sn position on the glycerol molecule of ST would affect both the overall hidrophobicity, which in turn may influence its solubility in water, and the incorporation into TAGs and/or phospholipids (Stein, 1999).

DSC thermograms, correlating temperature and normalized heat flow, are shown in Figures 1 and 2. Both chemical and enzymatic interesterification produced noteworthy changes in the melting profile, as already reported in another study (Rousseau and Marangoni, 2002).

The melting behavior of the samples varied markedly after the reactions because of the incorporation of MCFA into fish oil TAG, which originally contained mainly unsaturated fatty acids. This behavior was observed when using either the $\mathrm{MeC}_{10}$ or the Trigliceril $\mathrm{CM}^{\circledR}$ as substrate and was also due to a rearrangement of TAGs after the interesterification reactions, resulting in a higher complexity in TAG composition, as already established (Rousseau et al., 1996; Grimaldi et al., 1998; Grimaldi et al., 2001).

The melting profiles of the feedstock mixtures of Trigliceril $\mathrm{CM}^{\circledR}$ and ROPUFA ${ }^{\circledR}$ (Figure 1) were quite 


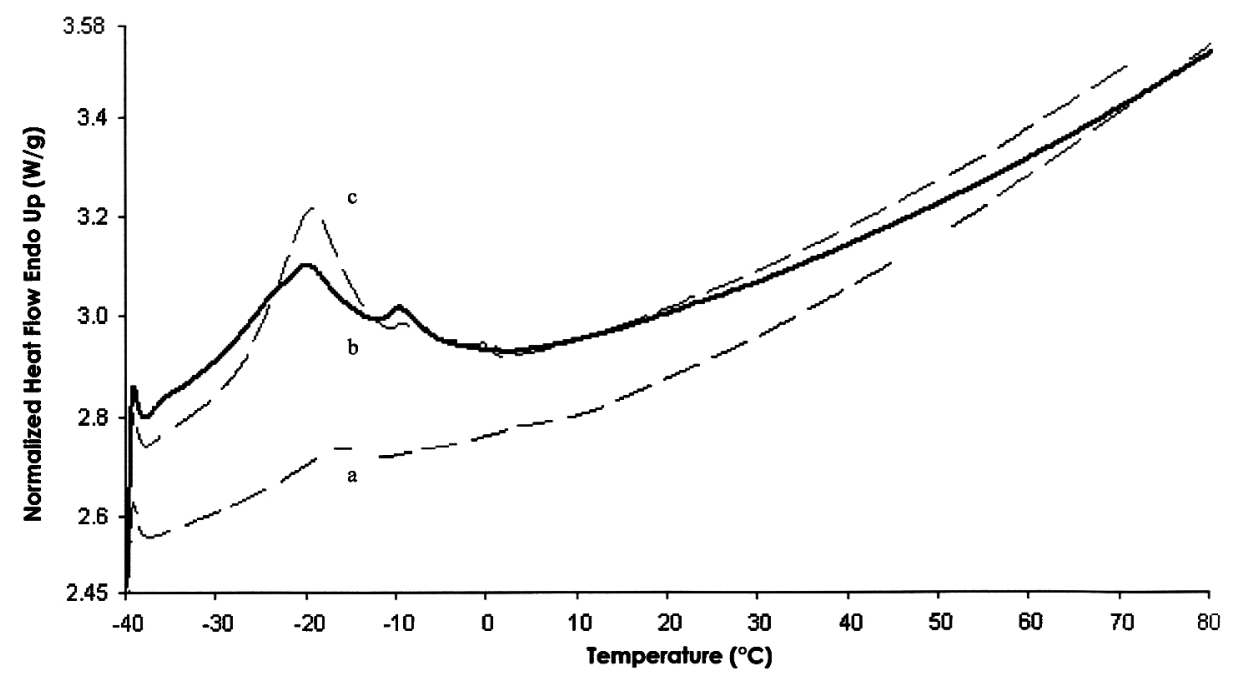

Figure 1.

DSC thermograms (melting curves) of the mixture Trigliceril $\mathrm{CM}^{\circledast}$ and ROPUFA ${ }^{\circledast}$ food oil (a) before interesterification; (b) after chemical interesterification; and (c) after enzymatic interesterification.

alike, with just one peak of similar shape, suggesting little difference between TAGs obtained by chemical and enzymatic interesterification.

The DSC thermograms of the fish oils interesterified with the $\mathrm{MeC}_{10}$ (Figure 2) exhibited a broad melting range, with two distinct peaks for the product of the chemical reaction, probably because of a random distribution of fatty acids in TAGs. The higher complexity of the thermograms shown in Figure 2 suggests a higher complexity of the STs obtained by the interesterification between the fish oil and the $\mathrm{MeC}_{10}$. This result could also be associated with the formation of TAGs without intersolubilization, which is consistent with other studies involving TAG modification (Rousseau et al., 1996; Nassu and Gonçalves, 1999).

Capric acid has a melting point greater than that of its methyl ester, thus leading to TAGs with a greater melting point. Further, capric acid has a melting point greater than that of caprylic acid, which in turn is the main fatty acid in the Trigliceril $\mathrm{CM}^{\circledR}$ (Bailey, 1979; ISEO, 2006). Hence, the thermograms shifted a few degrees higher when using $\mathrm{MeC}_{10}$ as acyl donor.

Information on the characteristic temperatures of the samples was obtained from thermograms and the values are shown in Table 2 . The very low or negative melting temperatures obtained for the oils can be attributed to the presence of unsaturated fatty acids in all samples, provided from the fish oil. This behavior has been already observed for salmon oil (Sathivel, 2005) and is a special feature of fish oils. According to another ST containing MCFAs and n-3 PUFAs mentioned in the United States Patent 6.608.223 (Rao et al., 2003), the STs obtained herein as a result of interesterification reactions

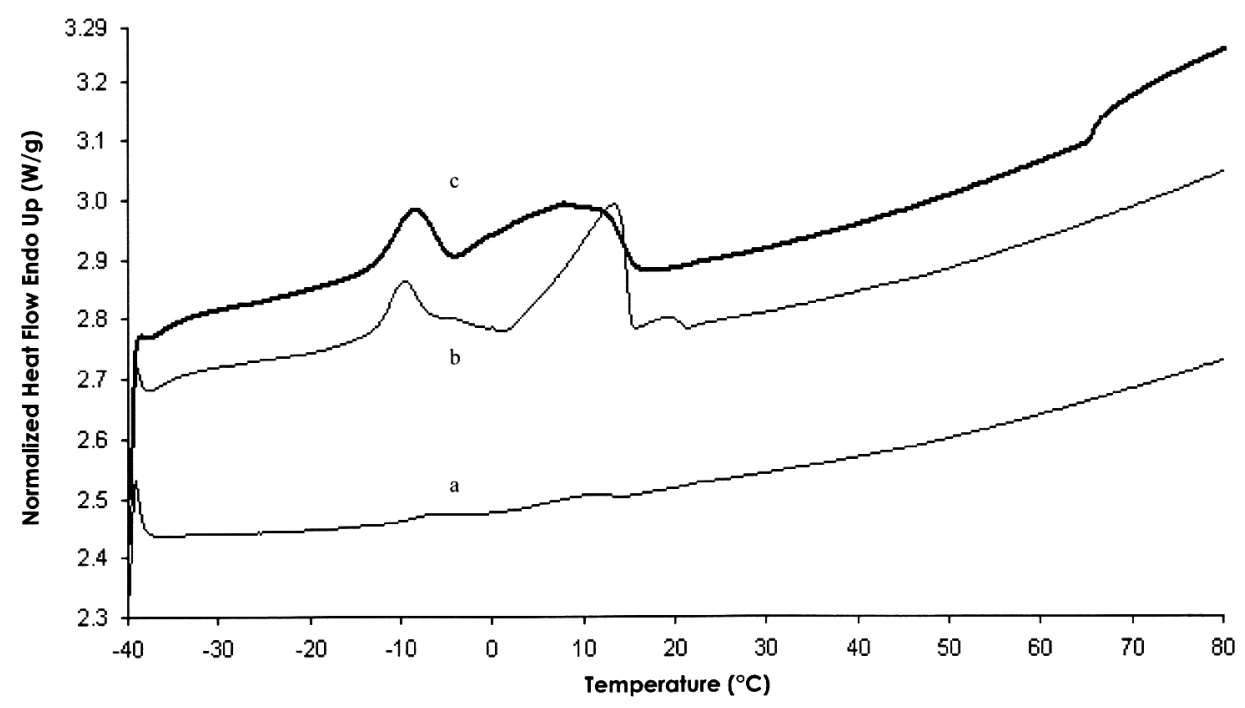

Figure 2.

DSC thermograms (melting curves) of the mixture $\mathrm{MeC}_{10}$ and ROPUFA ${ }^{\circledR}$ food oil (a) before interesterification; (b) after chemical interesterification; and (c) after enzymatic interesterification. 
Table 2

Data obtained from DSC melting curves of mixtures before and after chemical and enzymatic interesterification

\begin{tabular}{|c|c|c|c|c|c|c|c|}
\hline \multirow[b]{2}{*}{ Data } & \multirow[b]{2}{*}{ Peak } & \multicolumn{3}{|c|}{ Trigliceril CM $^{\circledR}+$ ROPUFA $^{\circledR}$} & \multicolumn{3}{|c|}{ MeC $_{10}+$ ROPUFA $^{\circledR}$} \\
\hline & & a & b & c & a & b & c \\
\hline \multirow[t]{2}{*}{ Peak temperature $\left({ }^{\circ} \mathrm{C}\right)$} & 1 & -17.3 & -19.5 & -20.3 & - & -9.7 & 7.7 \\
\hline & 2 & - & - & - & - & 13.3 & - \\
\hline \multirow[t]{2}{*}{ Onset temperature $\left({ }^{\circ} \mathrm{C}\right)$} & 1 & -25.7 & -37.1 & -37.5 & - & -13.1 & -15.6 \\
\hline & 2 & - & - & - & - & 1.3 & - \\
\hline \multirow[t]{2}{*}{ Initial melting point $\left({ }^{\circ} \mathrm{C}\right)$} & 1 & -27.0 & -37.1 & -37.7 & - & -19.5 & -15.6 \\
\hline & 2 & - & - & - & - & 1.3 & - \\
\hline \multirow[t]{2}{*}{ Final melting point $\left({ }^{\circ} \mathrm{C}\right)$} & 1 & -9.4 & 2.1 & 2.1 & 13.5 & 0.8 & 16.1 \\
\hline & 2 & - & - & - & - & 20.8 & - \\
\hline \multirow[t]{2}{*}{ Melting enthalpy $\left(\mathrm{J} \cdot \mathrm{g}^{-1}\right)$} & 1 & 5.1 & 65.1 & 52.4 & $\sim 0$ & 7.9 & 26.6 \\
\hline & 2 & - & - & - & - & 17.8 & - \\
\hline Total melting enthalpy $\left({\left.\mathrm{J} . \mathrm{g}^{-1}\right)}^{-1}\right.$ & - & 5.1 & 65.1 & 52.4 & $\sim 0$ & 25.7 & 26.6 \\
\hline
\end{tabular}

a) before interesterification; b) after chemical interesterification; c) after enzymatic interesterification.

displayed a melting behavior different from the one presented by original oil blends. In this present work, the STs had a melting temperature lower than the unmodified oil melting temperature, thus maintaining them in the liquid state even at low temperatures, without phase separation, which is important for their administration in enteral and parenteral nutrition (Jores, 2004). These STs have melting points below body temperature remaining liquid in the intestinal lumen, with a good digestion and absorption (Christophe, 1998). Some commercial STs such as Intralipid ${ }^{\circledR}$ (Férezou et al., 2001) and Captex $^{\circledR} 810$ (Bach and Babayan, 1982) applied for medical purposes are also available in the liquid state. The latter is a transesterified oil composed by linoleic acid along with caprylic and capric acids.

Melting enthalpy is the energy required for the complete melting of the sample (Nassu and Gonçalves, 1999; Grimaldi et al., 1998). The melting enthalpy values increased with decreasing I.V. of the samples (I.V. values already shown in Table 1), which in turn is related to a higher degree of saturated fatty acids in the sample, as already shown for other substrates (Nassu and Gonçalves, 1999). This result was evident in the case of the remaining products of both chemical and enzymatic interesterification of fish oil with Trigliceril $\mathrm{CM}^{\circledR}$, whereas the diversified fatty acid composition of TAGs resulted in a small deviation from this rule for the product of the incorporation of $\mathrm{MeC}_{10}$ into fish oil TAGs.

From the results shown in Figures 1 and 2 as well as in Table 2, it can be seen that the observed differences between samples were due to reaction conditions involving both the substrate and the catalyst.

\section{CONCLUSIONS}

This work confirmed the feasibility of the synthesis of structured TAGs containing both $n-3$ EPA and DHA, obtained from fish oil, and MCFA. We have also shown that the composition of the feedstock mixtures as well as the catalyst play an important role in the establishment of the fatty acid composition of the interesterified oils. We described the incorporation of MCFA into fish oil TAGs with the maintenance of a high EPA and DHA content mainly when using $\mathrm{MeC}_{10}$ as acyl donor in the enzymatic interesterification. The STs herein obtained have relatively high amounts of PUFAs accompanying the MCFAs. The STs thus obtained have potential application in clinical nutrition as an energy-yielding substrate rich in essential fatty acids, particularly beneficial for patients with malabsorption syndromes.

\section{ACKNOWLEDGMENTS}

The authors thank CAPES (Coordenação de Aperfeiçoamento de Pessoal de Nível Superior) for providing a Master's Fellowship, Novozymes, DSM Nutritional Products Ltd and Support Produtos Alimentícios Ltda. for donations, Prof. Francisco C. Deschamps (Empresa de Pesquisa Agropecuária e Extensão Rural de Santa Catarina S.A., Brazil) for his assistance in GC analysis and Prof. Luiz A. Gioielli (Universidade Estadual de São Paulo, Brazil) for his suggestions.

\section{REFERENCES}

Akoh CC. 1995. Structured lipids - Enzymatic approach. Inform 6, 1055-1061.

Akoh CC, Lee K-T, Fomuso LB. 1998. Synthesis of positional isomers of structured lipids with lipases as biocatalysts, in Christophe A (Ed.) Structural Modified Food Fats: Synthesis, Biochemistry, and Use. AOCS Press, Champaign, pp. 46-72.

AOCS. 1990. Official Methods and Recommended Practices of the American Oil Chemists' Society. 4th ed, AOCS Press, Champaign.

AOCS. 1997. Official Methods and Recommended Practices of the American Oil Chemists' Society. 5th ed, AOCS Press, Champaign.

Aro T, Tahvonen R, Mattila T, Nurmi J, Sivonen T, Kallio H. 2000. Effects of season and processing on oil content 
and fatty acids of Baltic herring (Clupea harengus membras). J. Agr. Food Chem. 48, 6085-6093.

Bach A, Babayan VK. 1982. Medium-chain triglycerides: an update. Am. J. Clin. Res. 32, 950-962.

Bailey AE. 1979. Bailey's Industrial Oil and Fat Products. 4th ed, John Wiley \& Sons, New York.

Bell SJ, Bradley D. 1997. The new dietary fats in health and disease. J. Am. Diet Assoc. 97, 280-286.

Bistrian BR. 1997. Novel lipid sources in parenteral and enteral nutrition. Proceed Nutr. Soc 56, 471-477.

Bockisch M. 1993. Fats and Oils Handbook. AOCS Press, Champaign.

Bourque C, St-Onge M-P, Papamandjaris AA, Cohn JS, Jones PJH. 2003. Consumption of an oil composed of medium chain triacylglycerols, phytosterols, and $n-3$ fatty acids improves cardiovascular risk profile in overweight women. Metabolism 52, 771-777.

Carpentier YA. 2008. Basic in clinical nutrition: substrates used in parenteral and enteral nutrition-lipids. $e$ SPEN, Eur e-J Clin. Nutr. Metab. doi:10.1016/ j.ecinm.2008.07.009.

Cater NB, Heller HJ, Denke MA. 1997. Comparison of the effects of medium-chain triacylglycerols, palm oil, and high oleic acid sunflower oil on plasma triacylglycerol fatty acids and lipid and lipoprotein concentrations in humans. Am. J. Clin. Nutr. 65, 41-45.

Christie WW. 1982. Lipid Analysis. 2nd ed, Pergamon Press, Oxford.

Christophe A. 1998. Metabolism and physiological effects of dietary fats in relation to their structure, in Christophe A (Ed.) Structural Modified Food Fats: Synthesis, Biochemistry, and Use. AOCS Press, Champaign, pp. 139-148.

Díaz Gamboa O, Gioielli LA. 2003a. Consistencia de lípidos estructurados a partir de aceite de pescado y grasa de palmiste. Grasas y Aceites 54,122-129.

Díaz Gamboa O, Gioielli LA. 2003b. Lípidos estructurados obtenidos por interesterificación química y enzimática a partir de aceite de pescado y grasa de palmiste. Grasas y Aceites 54, 161-168.

Dunford NT. 2004. Oil- and oilseed-based bioactive compounds and their health effects, in Dunford NT, Dunford HB. (Ed.) Nutritionally Enhanced Edible Oil and Oilseed Processing. AOCS Press, Champaign, pp. 1-24.

Férézou J, Gulik A, Domingo N, Milliat F, Dedieu J-C, Dunel-Erb S, Chevalier C, Bach AC. 2001. Intralipid 10\%: physicochemical characterization. Nutrition 17 , 930-933.

Food and Agriculture Organization/World Health Organization - FAO-WHO, CODEX ALIMENTARIUS. 1981, revision 1999. Codex Standard for Edible Fats and Oils not Covered by Individual Standards, CODEX-STAN 19.

Food and Drug Administration - FDA. 1995, revision 2003. Code of Federal Regulations: 21 CFR 184 Direct Food Substances affirmed as Generally Recognized as Safe.

Galante JH, Tenore RR. 2006. Medium-chain triglycerides, in Akoh CC (Ed.) Handbook of Functional Lipids - Functional Foods and Nutraceuticals. CRC Press, Boca Ratón, pp. 177-184.

Goldberg I (Ed.). 1994. Functional Foods: Designer Foods, Pharmafoods, Nutraceuticals. Chapman \& Hall, New York.

Grimaldi R, Gonçalves LAG, Gioielli LA, Simões IS. 2001. Interactions in interesterified palm and palm kernel oils mixtures. II - Microscopy and differential scanning calorimetry. Grasas y Aceites 52, 363-368.
Grimaldi R, Nassu RT, Gonçalves LAG, Moreira RNC. 1998. Characterization of hydrogenated fats for margarine manufacturing purposes. Grasas y Aceites 49, 1-8.

Gunstone FD. 1999. Enzymes as biocatalysts in the modification of natural lipids. Review. J. Sci. Food Agr. 79, 1535-1549.

Gunstone FD, Harwood JL, Padley FB. 1994. Marine oils: fish and whale oils, in Gunstone FD, Harwood JL, Padley FB. (Ed.) The Lipid Handbook. Chapman \& Hall, London, pp. 167-395.

Hartman L, Lago RCA. 1973. Rapid preparation of fatty acid methyl esters from lipids. Lab. Pract. 22, 475-477.

Hartvigsen MS, Mu H, Hoy C-E. 2003. Influence of maternal dietary n-3 fatty acids on breast milk and liver lipids of rat dams and offspring - a preliminary study. Nutr. Res. 23, 747-760.

Hasselmann M, Kummerlen C. 1998. Les lipides intraveineux: aspects qualitatifs. Nutr. Clin. Métab. 12, 117-126.

Institute of Shortening and Edible Oils - ISEO. 2006. Food Fats and Oils. Institute of Shortening and Edible Oils, New York.

Jandacek RJ, Whiteside JA, Holcombe BN, Volpenhein RA, Taulbee JD. 1987. The rapid hydrolysis and efficient absorption of triglycerides with octanoic acid in the 1 and 3 positions and long-chain fatty acid in the 2 position. Am. J. Clin. Nutr. 45, 940-945.

Jennings BH, Akoh CC. 1999. Enzymatic modification of triacylglycerols of high eicosapentaenoic and docosahexaenoic acids content to produce structured lipids. J. Am. Oil Chem. Soc. 76, 1133-1137.

Jennings BH, Akoh CC. 2001. Lipase catalyzed modification of fish oil to incorporate capric acid. Food Chem. 72, 273-278.

Jones PM, Butt Y, Messmer B, Boriak R, Bennett MJ. 2006. Medium-chain fatty acids undergo elongation before $\beta$-oxidation in fibroblasts. Biochem. Biophys. Res Commun. 346, 193-197.

Jores K. 2004. Lipid Nanodispersions as Drug Carrier Systems - A Physicochemical Characterization. Ph.D. Thesis. Martin-Luther-Universität Halle-Wittenberg, Germany. 111 p.

Klinkesorn U, H-Kittikun A, Chinachoti P, Sophanodora P. 2004. Chemical transesterification of tuna oil to enriched omega-3 polyunsaturated fatty acids. Food Chem. 87, 415-421.

Kris-Etherton PM, Harris WS, Appel LJ. 2002. Fish consumption, fish oil, omega-3 fatty acids, and cardiovascular disease. Circulation 106, 2747-2757.

Kubow S. 1996. The influence of positional distribution of fatty acids in native, interesterified and structurespecific lipids on lipoprotein metabolism and atherogenesis. J. Nutr. Biochem. 7, 530-541.

Lands WEM. 2002. Fish, Omega-3 and Human Health. 2nd ed, AOCS Press, Champaign.

Macrae AR. 1983. Lipase-catalyzed interesterification of oils and fats. J. Am. Oil Chem. Soc 60, 243-246.

Marangoni AG, Rousseau D. 1995. Engineering triacylglycerols: the role of interesterification. Trends Food Sci. Tech. 6, 329-335.

Matulka RA, Noguchi O, Nosaka N. 2006. Safety evaluation of a medium- and long-chain triacylglycerol oil produced from medium-chain triacylglycerols and edible vegetable oil. Food Chem. Toxic. 44, 15301538.

Moura JMLN de, Gonçalves LAG, Grimaldi R, Soares M da S, Ribeiro APB. 2006. Otimização das condições de produção de ésteres etílicos a partir de óleo de 
peixe com elevado teor de ácido graxos w-3. Quím. Nova 29, 956-959.

$\mathrm{Mu} \mathrm{H}$, Hoy C-E. 2000. Effects of different medium-chain fatty acids on intestinal absorption of structured triacylglycerols. Lipids 35, 83-89.

Mu H, Hoy C-E. 2001. Intestinal absorption of specific structured triacylglycerols. J. Lip Res. 42, 792-798.

$\mathrm{Mu} \mathrm{H}$, Porsgaard T. 2005. The metabolism of structured triacylglycerols. Progr. Lip. Res. 44, 430-448.

Nassu RT, Gonçalves LAG. 1999. Determination of melting point of vegetable oils and fats by differential scanning calorimetry (DSC) technique. Grasas $y$ Aceites 50, 16-22.

Nicolosi RJ. 1997. Dietary fat saturation effects on lowdensity-lipoprotein concentrations and metabolism in various animal models. Am. J. Clin. Nutr. 65 (suppl), 1617S-1627S.

Nielsen NS, Göttsche JR, Holm J, Xu X, Mu H, Jacobsen C. 2005. Effect of structured lipids based on fish oil on growth and fatty acid composition in rainbow trout (Oncorhynchus mykiss). Aquaculture 250, 411-123.

Osborn HT, Akoh CC. 2002. Structured lipids - novel fats with medical, nutraceutical, and food applications. Compr. Rev. Food Sci. Food Saf. 1, 93-103.

Pacheco MTB, Barrera-Arellano D. 1994. Fraccionamiento del aceite de hígado de tiburón azul (Prionace glauca) y su estabilización con antioxidantes. Grasas y Aceites 45, 155-160.

Pigott GM, Tucker BW. 1990. Seafood: Effects of Technology on Nutrition. Marcel Dekker, Inc., New York.

Qi K, Seo T, Jiang Z, Carpentier YA, Deckelbaum RJ. 2006. Triglycerides in fish oil affect the blood clearance of lipid emulsions containing long- and medium-chain triglycerides in mice. J. Nutr. 136, 2766-2772.

Rao R, Sambaiah K, Lokesh BR. 2003. Cholesterol lowering structured lipids containing omega-3 polyunsaturated fatty acids and their process thereof. Patent no US 6.608.223 B2.

Reyes HR, Hill Jr CG. 1994. Kinetic modeling of interesterification reactions catalyzed by immobilized lipase. Biotechnol Bioeng. 43, 171-182.

Rousseau D, Forestière K, Hill AR, Marangoni AG. 1996. Restructuring butterfat through blending and chemical interesterification. 1. Melting behavior and triacylglycerol modifications. J. Am. Oil Chem. Soc. 73, 963-972.

Rousseau D, Marangoni AG. 2002. The effects of interesterification on the physical properties of fats, in
Marangoni, AG, Narine SS. (Ed.) Physical Properties of Lipids. Marcel Dekker, Inc., New York, pp. 479-527.

Sathivel S. 2005. Thermal and flow properties of oils from salmon heads. J. Am. Oil Chem. Soc. 82, 147-152.

Shimada Y. 2006. Enzymatic modification of lipids for functional foods and nutraceuticals, in Akoh CC (Ed.) Handbook of Functional Lipids - Functional Foods and Nutraceuticals. CRC Press, Boca Ratón, pp. 437456.

Simoens CM, Deckelbaum RJ, Massaut JJ, Carpentier YA. 2008. Inclusion of $10 \%$ fish oil in mixed mediumchain triacylglycerol-long-chain triacylglycerol emulsions increases plasma triacylglycerol clearance and induces rapid eicosapentaenoic acid (20:5n-3) incorporation into blood cell phospholipids. Am. J. Clin. Nutr. 88, 282-288.

Soccol MCH, Oetterer M. 2003. Seafood as functional food. Braz. Arch. Biol Techn. 46, 443-454.

Stein J. 1999. Chemically defined structured lipids current status and future directions in gastrointestinal diseases. Int. J. Colorectal Dis. 14, 79-85.

St-Onge M-P. 2005. Dietary fats, teas, dairy, and nuts: potential functional foods for weight control? Am. J. Clin. Nutr. 81, 7-15.

St-Onge M-P, Bosarge A. 2008. Weight-loss diet that includes consumption of medium-chain triacylglycerol oil leads to a greater rate of weight and fat mass loss than does olive oil. Am. J. Clin. Nutr. 87, 621-626.

Straarup EM, Hoy C-E. 2000. Structured lipids improve fat absorption in normal and malabsorbing rats. J. Nutr. 130, 2802-2808.

Versleijen M, Roelofs H, Preijers F, Roos D, Wanten G. 2005. Parenteral lipids modulate leukocyte phenotypes in whole blood, depending on their fatty acid composition. Clin. Nutr. 24, 822-829.

Wanasundara UN, Shahidi F. 1998. Antioxidant and prooxidant activity of green tea extracts in marine oils. Food Chem. 63, 335-342.

Willis W, Lencki RW, Marangoni AG. 1998. Lipid modification strategies in the production of nutritionally functional fats and oils. Critical Reviews Food Sci. Nutr. 38, 639-674.

Xu X. 2004. Biocatalysis for lipid modifications, in Dunford NT, Dunford HB. (Ed.) Nutritionally Enhanced Edible Oil and Oilseed Processing. AOCS Press, Champaign, pp. 239-263.

Recibido: $3 / 7 / 08$ Aceptado: 28/10/08 